\title{
Countering Economic Crime in The Context of Globalization
}

\author{
Svetlana Markina ${ }^{1 *}$, Roman Artemov ${ }^{1}$, Ekaterina Nosachevskaya $^{1}$, and Vladimir Panskov ${ }^{2}$ \\ ${ }^{1}$ Southwest State University, Faculty of Economics and Manaqement, Department of Economic \\ Security and Taxation, Kursk, 50 Let Oktyabrya Street, 94, Russia. \\ ${ }^{2}$ Financial University under the government of the Russian Federation, Moscow, Russia.
}

\begin{abstract}
.
Research background: The criminalization of public relations in the context of economic globalization is one of the hallmarks of modernity. The study of world, Russian and regional trends and patterns of economic crime and its conditionality by globalization processes in the world are of particular relevance. The transformation of national crime into transnational international forms in the context of globalization of political, economic, information and communication processes is an integral part of globalization. And this reality confronts science with the need to develop measures to combat economic crime.

Purpose of the article: the formation of an effective mechanism to prevent the spread and combat economic criminal activity.

Methods: methods of expert assessments, macroeconomic assessments, methods of classification, grouping, economic and statistical analysis, methods of criminological forecasting.

Findings \& Value added: The proposed mechanism for preventing the spread and combating economic criminal activity will make it possible to make full use of preventive opportunities, timely and adequately respond to administrative and other offenses, to fully use administrative and legal means of influencing criminogenic factors and measures provided for by criminal procedure and other legislation ... In order to improve methods for assessing the effectiveness of internal affairs bodies in countering economic crimes, a model is proposed for assessing the results of the activities of territorial bodies of the Ministry of Internal Affairs of Russia, aimed at reflecting the activities of internal affairs bodies and individual employees by assessing the degree of achievement of their tasks. The introduction of the designated criteria and indicators of the effectiveness of the internal affairs bodies within the framework of the proposed model will make it possible to bring the existing system of assessing the activities of the internal affairs bodies closer to the goal of reforming the internal affairs bodies focusing on public opinion and evaluation by the main consumer of law enforcement services - society.
\end{abstract}

Corresponding author: markinas@list.ru 
Keywords: economic crime; shadow economy; economic globalization; world economy; legal business; criminal business.

JEL Classification: $F 69 ; P 37 ; O 17$

\section{Introduction}

The fight against crime in the economic sphere is relevant at all stages of state development, regardless of the emerging socio-economic and socio-political situation. These crimes affect all types of economic activity, are reflected in various areas of society. Crimes committed in the economic sphere during the reform period covered both long-standing structures of state and public property, and enterprises of other forms of ownership - private enterprises, joint stock companies, various kinds of partnerships, and the like.

In such conditions, the state bears huge losses in the economic sphere, which determines our interest in studying the subjects of ensuring economic security. One of such subjects is the internal affairs bodies.

The relevance of the research topic is due to the need to study and improve the methodology for assessing the effectiveness of the internal affairs bodies and their management apparatus, which would focus on such criteria and indicators that would correspond to the interests and requirements of the main consumer of law enforcement "services" - the population, and coincide with those criteria, by which it predominantly evaluates their activities. Efficiency can be represented by scales of different indicators, but in general, they should reflect the objective result of the activities of a specialized institute, with the help of which it is only possible to improve the functional and structural parameters of the system of internal affairs bodies and their administrative apparatus, to adjust goals and objectives in accordance with the assessments of various social strata and groups of citizens.

The globalization processes taking place in the world community are accompanied by the rapid development of transnational (international) organized crime. The confrontation between the power of various world powers and organized crime has been going on for hundreds of years. Some historians note that even during the Roman Empire, the existence of such groups was a huge problem for the state, since they tried to control certain areas of the economy. Globalization, which has changed the format of international relations, has to some extent "played along" with transnational criminals. The growth in investment and the development of international trade, the creation and rapid implementation of the Internet, which greatly simplifies the exchange of information, ensured transparency of borders, and thus a number of levers that previously allowed to resist international crime were "snatched" from the hands of the governments of different countries of the world. In general, the world community in the modern historical period is distinguished by a wide spread of transnational organized crime and an increase in this connection with a real threat to the national security of Russia and other world powers.

Thus, for Russia, one of the possible directions of state policy in the field of effective countering transnational organized crime and ensuring national security is to optimize the management structure of law enforcement agencies, strengthen and develop cooperation with law enforcement agencies of the CIS countries, as well as with the intelligence services of other states, especially those that are geopolitical allies. RF.

\section{Literature review}

The processes of globalization of economic relations as a manifestation of the objective laws of the development of productive forces and production relations determine the need, the nature of the institutions of legal regulation and protection. In this regard, legal relations in 
the economic sphere are an important aspect in the case of criminal legal protection and depend on the specifics of the existing economic relations.

Consequently, in order to study the problems associated with the essential side of criminal law relations, it seems logical to study issues of a completely different order. As such, public relations in the economic sphere can act, which, along with other public relations, need legal protection from the state. Any state entity is interested in its stable existence, and stability can only be ensured by a state guarantee of the development of economic relations from economic crimes [1].

The problem of studying economic crimes has attracted the attention of scientists and practitioners since the historical emergence of this social phenomenon. Despite the widespread use of the concept in science, in economic activities, definitions given in criminological or criminal practice are most often used.

The development of effective strategies to combat crime in the economic sphere largely depends on what we understand by the term "economic crime".

The concept of economic crime is borrowed from Western teachings. Sociocriminologist Edwin Sutherland introduced the concept of "whitecollar crime" into scientific circulation in 1940 , drawing attention to the social danger of crimes committed by respectable persons (businessmen and people of certain professions) in the course of their activities. Then this concept was transformed and became synonymous with corporate crime - crimes committed by corporations [2] .

B. Svenson in his work "Economic Crime" pointed out that economic crime includes, first of all, such crime, the immediate motive of which is economic benefit. In addition, it must be of a continuing nature, carried out systematically and within the framework of economic activity, which in itself is not criminally punishable, but in certain cases forms the basis of criminal activity [3].

ON THE. Lopashenko points to the ambiguity and contradictory nature of scientific views that characterize economic crime. The author interprets this concept as crime formed by crimes in the sphere of economic activity or even a part of them, the identification of economic crime with mercenary crime, as well as a broad understanding of economic crime, that is, as crime consisting of crimes against property and crimes in the sphere of economic activity [4] .

VV Luneev believes that the basis of economic crime in countries with market economies is the crimes committed by corporations against the state economy, against other corporations, serving corporations against the corporation itself, corporations against consumers [5] .

The works [6-8] analyze the problems of the shadow economy, which are highly controversial among researchers.

The framework is a current first article was, and the results used in research Started $\mathrm{t}$ [9$10]$.

The fight against crime in the economic sphere is closely related to and with the assessment of economic security in the fiscal and the impact of environmental and economic factors [11-14 ].

\section{Results}

Russia entered the top 5 countries where companies most often suffer from economic crime. This follows from a review by PricewaterhouseCoopers ( PwC ) "Combating Fraud: What Measures Are Companies Taking?" (available from RBC), as well as additional data provided by $\mathrm{PwC}$. In the Russian survey, crimes are understood as actions that are qualified as such by the companies themselves, and not by law enforcement agencies, and are not necessarily formalized in criminal cases, PwC explained [15] . 
Consider the share of economic crimes in the total number of crimes in Table 1 .

As can be seen from Table 1, the number of economic crimes decreased in 2019 by $62.27 \%$ compared to 2010 . This indicator also tends to decrease.

Table 1. The share of economic crimes in the total number of crimes in Russia

\begin{tabular}{|l|c|c|c|c|c|c|c|c|c|c|}
\hline $\begin{array}{l}\text { Indicato } \\
\text { rs }\end{array}$ & 2010 & 2011 & 2012 & 2013 & 2014 & 2015 & 2016 & 2017 & 2018 & 2019 \\
\hline $\begin{array}{l}\text { Total } \\
\text { crimes }\end{array}$ & 2628799 & 2104807 & 2302168 & 2206249 & 2190578 & 2388476 & 2160063 & $\begin{array}{c}20584 \\
76\end{array}$ & $\begin{array}{c}19915 \\
32\end{array}$ & 2024337 \\
\hline $\begin{array}{l}\text { Includi } \\
\text { ng } \\
\text { econom } \\
\text { ic } \\
\text { crimes }\end{array}$ & 276435 & 202454 & 172975 & 141229 & 107797 & 112445 & 108754 & $\begin{array}{c}10508 \\
7\end{array}$ & $\begin{array}{c}10946 \\
3\end{array}$ & 104297 \\
\hline $\begin{array}{l}\text { The } \\
\text { share of } \\
\text { econom } \\
\text { ic } \\
\text { crimes } \\
\text { in the } \\
\text { total } \\
\text { number } \\
\text { of } \\
\text { crimes }\end{array}$ & 10.52 & 9.62 & 7.51 & 6.40 & 4.92 & 4.71 & 5.03 & 5.11 & 5.5 & 5.15 \\
\hline
\end{tabular}

As for the share of economic crimes in the total number of crimes, it can be noted that this indicator was decreasing until 2015. Since 2016, there has been some instability of this indicator, in the period from 2016-2019. the investigated indicator does not exceed 6\%. So, in 2019 , the share of economic crimes amounted to $5.15 \%$ of the total number of crimes.

Based on Table 2, we note that the amount of material damage increased by 1.5 times in 2019 compared to 2010. However, in the period 2010-2012, this indicator decreased. Further, since 2013, this indicator has an unstable trend. So, in 2019, material damage from economic crimes amounted to 447.19 billion rubles .

Table 2. Analysis of victims of criminal encroachments and material damage from economic crimes in Russia

\begin{tabular}{|l|c|c|c|c|c|c|c|c|c|c|}
\hline \multicolumn{1}{|c|}{ Indicators } & 2010 & 2011 & 2012 & 2013 & 2014 & 2015 & 2016 & 2017 & 2018 & 2019 \\
\hline $\begin{array}{l}\text { Material } \\
\text { damage, } \\
\text { RUB bln }\end{array}$ & 176.4 & 160.7 & 144.8 & 229.8 & 194.5 & 271.4 & 397.9 & 234.2 & 403.8 & 447.1 \\
\hline $\begin{array}{l}\text { Number of } \\
\text { persons who } \\
\text { died from } \\
\text { criminal } \\
\text { encroachments }\end{array}$ & 96 & 83 & 247 & 116 & 138 & 244 & 250 & 426 & 353 & 66 \\
\hline $\begin{array}{l}\text { Number of } \\
\text { persons who } \\
\text { have suffered } \\
\text { serious harm } \\
\text { to health }\end{array}$ & 57 & 24 & 397 & 35 & 40 & 93 & 74 & 140 & 181 & 46 \\
\hline
\end{tabular}

The number of people who died from criminal offenses decreased in the period from 2010 to 2019 by $31.25 \%$ times. The largest number of persons who died from criminal offenses is observed in 2017. It is also worth noting that, compared to 2018, in 2019 this indicator decreased by $81.1 \%$.

After analyzing the dynamics of economic crimes by type, we note that there is a decrease in the number of crimes for all types. Thus, crimes against property are characterized by a downward trend throughout the entire analyzed period $((-61.61 \%)$ in 2019 compared to 2010).

With regard to crimes in the economic sphere, there is an unstable trend. The maximum value of the indicator is observed in 2010 (57162), and the lowest - in 2014 (26737). In general, in 2019 this indicator decreased by $33.89 \%$ compared to 2010 . However, compared 
with 2018, in 2019 there is an increase in the number of crimes in the field of economic activity by 1245 .

A similar trend is inherent in crimes against the interests of service in commercial and other organizations, as well as against state power, the interests of the civil service and service in local self-government bodies.

With regard to the structure of economic crimes, we note that in 2019 the largest share is occupied by crimes in the field of economic activity (44\%) and crimes against the interests of service in commercial and other organizations $(38 \%)$.

After analyzing the dynamics of crimes in the economic sphere, it can be noted that the most numerous are crimes related to the manufacture, storage, transportation or sale of counterfeit money or securities. This indicator has been decreasing throughout the entire analyzed period ((-54.1\%) in 2019 compared to 2010$)$.

Crimes related to the production, acquisition, storage, transportation or sale of goods and products without marking and (or) applying information provided for by the legislation of the Russian Federation have a negative trend throughout the analyzed period. Thus, this indicator increased 2.3 times in 2019 compared to 2010.

The number of crimes related to bankruptcy tends to decrease throughout the analyzed period. So, this indicator in 2019 decreased by $59.5 \%$ compared to 2010 .

There is also a decrease in the number of such crimes as illegal entrepreneurship (($62.3 \%$ ) in 2019 compared to 2010) and legalization (laundering) of money or other property acquired by a person as a result of a crime ((-46, 3\%) in 2019 compared to 2010$)$.

After analyzing the indicators of economic crimes, it can be noted that for the entire analyzed period, the number of registered, preliminary investigated, and also not solved economic crimes tends to decrease .

The number of pre-investigated economic crimes decreased by $68.45 \%$ in 2019 compared to 2010 . The number of unsolved crimes has also dropped. So, there is a decrease in this indicator by $57.42 \%$ in 2019 compared to 2010 .

The number of identified persons who committed crimes of an economic nature decreased in 2019 by $56.5 \%$ compared to 2010 and also tends to decrease throughout the entire analyzed period.

In table 3, we will analyze the indicators of criminal proceedings for economic crimes.

From table 3, we can note the following:

1) the number of considered cases on economic crimes has a steady upward trend. Thus, this indicator increased 1.4 times in 2018 compared to 2014;

2 ) the number of convicts clearly prevails over the acquitted. The number of the former also increases throughout the analyzed period. So, in 2018, the number of convicts increased by 4.5 times compared to 2014 .

Table 3. Analysis of indicators of criminal proceedings for economic crimes in Russia

\begin{tabular}{|l|l|l|l|l|l|l|}
\hline Indicators & 2014 & 2015 & 2016 & 2017 & 2018 & $\begin{array}{c}+,- \\
\%\end{array}$ \\
\hline Cases reviewed & 4207 & 4909 & 5868 & 7223 & 10267 & 144.05 \\
\hline Number of persons on cases & 4684 & 5475 & 6931 & 8284 & 11538 & 146.33 \\
\hline Condemned & 3691 & 4335 & 5667 & 6456 & 8243 & 123.33 \\
\hline Justified & 34 & 24 & 32 & 32 & 41 & 20.59 \\
\hline $\begin{array}{l}\text { Terminated criminal cases on } \\
\text { exonerating grounds }\end{array}$ & 22 & 4 & 57 & 20 & 5 & -77.27 \\
\hline Condemned in a special order & 2470 & 3076 & 3709 & 4173 & 5434 & 120 \\
\hline
\end{tabular}

Thus, the analysis of economic crime in the Russian Federation shows that the number of economic crimes tends to decrease, the share of economic crimes in the total number of crimes also decreases throughout the analyzed period. Material damage from economic 
crimes has an unstable trend in the period 2010-2019.In 2019, this indicator amounted to 447.19 billion rubles. The largest share in economic crimes in 2019 is occupied by crimes in the field of economic activity (44\%). And the largest share among the latter is occupied by crimes related to the manufacture, storage, transportation or sale of counterfeit money or securities.

We value the effectiveness of the activities of the internal affairs bodies in combating economic crimes in the Russian Federation, using coefficients and statistical individual indices.

Ideally, the rate of solution is one, that is, all registered crimes are solved. However, this coefficient, starting from 2014, is 0.6 . The highest value of the disclosure ratio is observed in 2010 (Fig . 1).

The crime rate is a specific generalized indicator of the total number of recorded crimes, correlated with the population [16]. It is determined by the number of crimes per 100 thousand, 10 thousand or 1 thousand of the population and is an objective measure of crime, allowing you to compare its levels in different regions and for different periods of time.

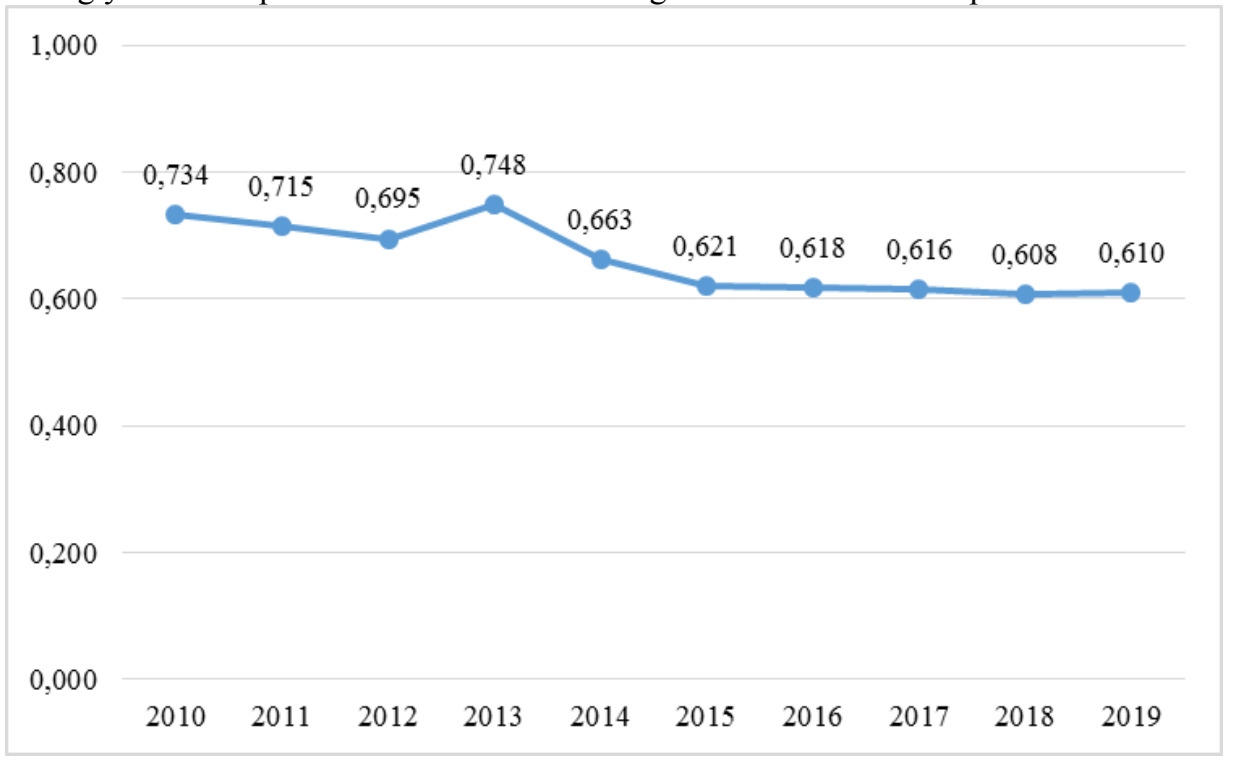

Fig. 1. Dynamics of the coefficient of solving economic crimes in Russia

During the analyzed period, the studied indicator decreases ((-63.05\%) in 2019 compared to 2010) (Fig . 2). The highest value of the coefficient of economic crime is observed in 2010. 


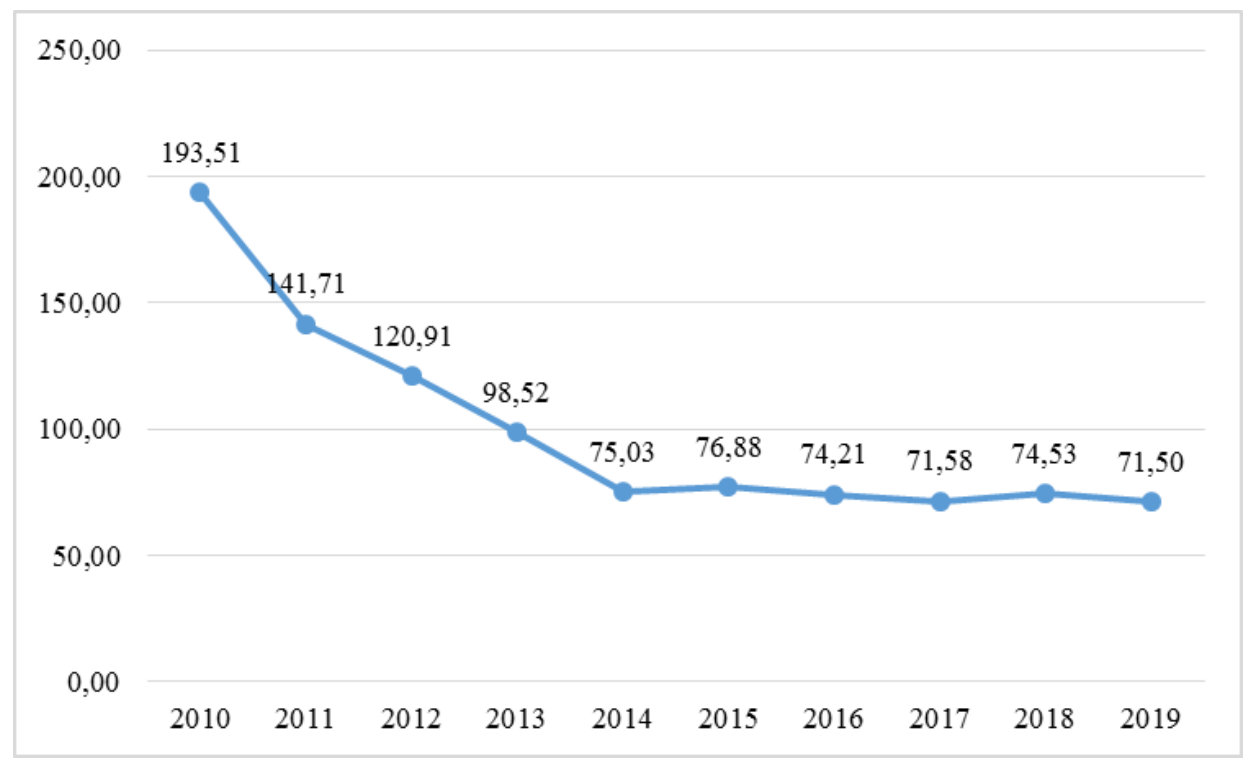

Fig. 2. Dynamics of the economic crime rate in Russia

Further, taking into account the above data and information presented on the portal of legal statistics, we will calculate the index of economic criminal activity in the Russian Federation.

The index of criminal activity during the analyzed period tends to decrease, which can be seen in Figure 3. The highest value of the index is observed in 2010. In general, this indicator decreased by $63.05 \%$ in 2019 compared to 2010 .

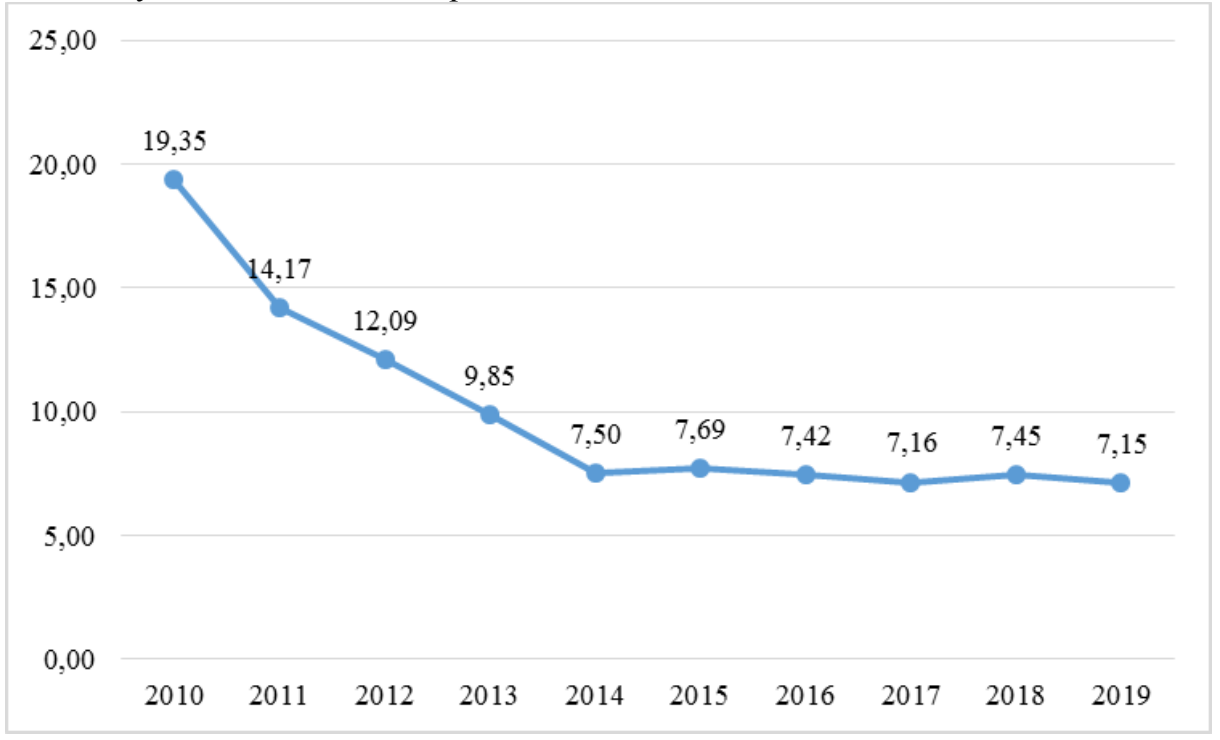

Fig. 3. Dynamics of the index of criminal activity in Russia

Thus, despite the fact that the dynamics of the detection rate for the analyzed period is negative, the value of this indicator in the period in 2019 is quite high, which indicates a fairly effective activity of the internal affairs bodies of the Russian Federation in countering economic crimes. 


\section{Discussion and conclusion}

In order to improve methods for assessing the effectiveness of internal affairs bodies in countering economic crimes, a general model is proposed for assessing the performance of $\mathrm{N}(\mathrm{n}=1,2, \ldots, \mathrm{N})$ of territorial bodies of the Ministry of Internal Affairs of Russia in $\mathrm{T}(\mathrm{t}=$ $1,2, \ldots, \mathrm{T})$ years is presented as an indicator ( Pit ), defined as the ratio of solved crimes ( Yit ) to the actual level of crime ( Qit ) in territory i during time period t:

$$
Q_{i t} P_{i t}=\frac{Y_{i t}}{Q_{i t}}
$$

Let's consider this mechanism in more detail. So, we have a hypothetical crime rate q1, due to the detection of crimes, it will be reduced to $\mathrm{q} 2$, which will lead to a higher rate of change of q2, etc. Thus, law enforcement agencies determine Pit, and potential offenders Qit. The crime rate and the solvability of crimes will tend to a stable balance. In graphical form, this ratio is shown in Figure 4, where the abscissa shows the crime rate ( Qit), and the ordinate shows the resolvability ( Pit).

Interpreting this model, we can say that negative socio-economic factors ( Xit ) decrease the Pit coefficient, increase the crime rate (Qit) and, accordingly, the crime detection rate ( Rit ) [17]. The activity of law enforcement agencies ( Uit) increases the coefficient of decidability ( by Pit ) and reduces crime ( QIT ).

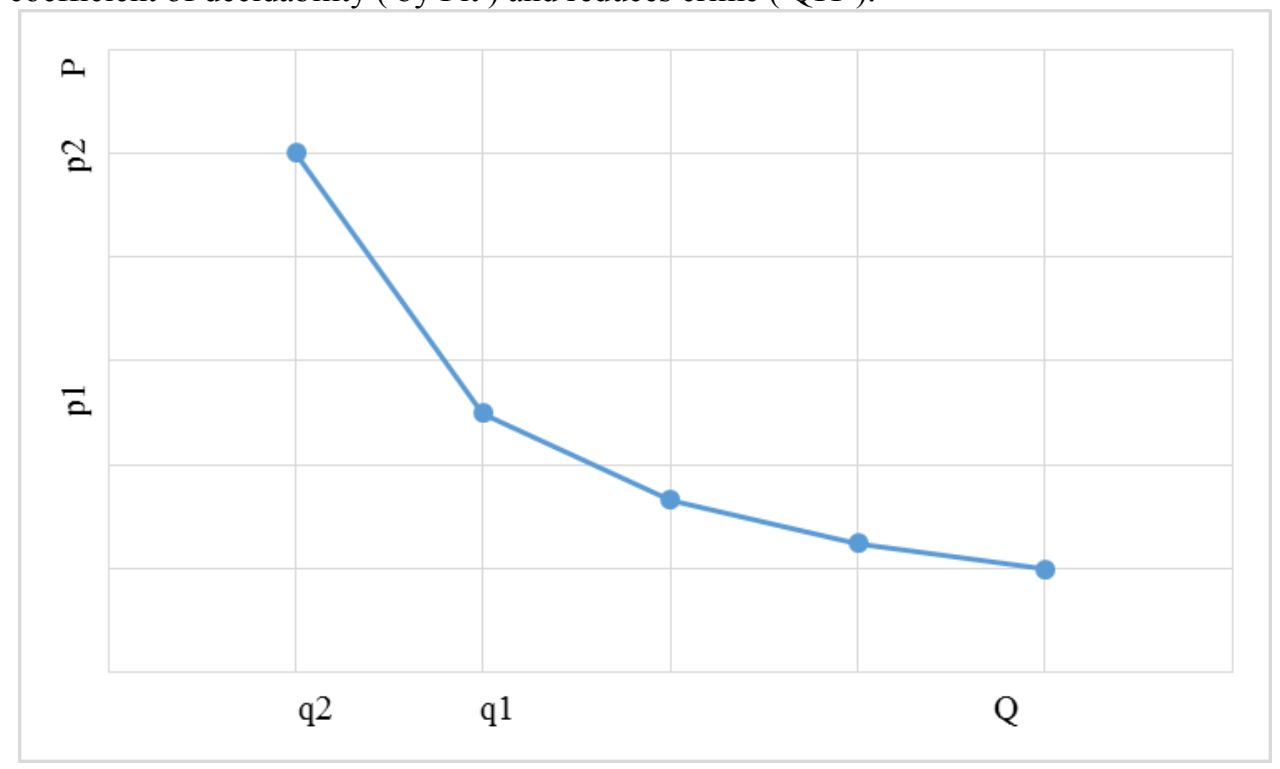

Fig. 4. Solvability of crimes

Today the Russian society faces a difficult task - effective counteraction to economic crime by influencing the factors that give rise to it. Over the past two or three years, the state has been taking not indisputable, but quite consistent steps in this direction.

In order to combat economic crime, the state needs to:

- to expand the scope of the existing legal framework for combating economic crimes, as well as to achieve its maximum implementation;

- to modernize state bodies fighting economic crimes;

- to ensure political and economic stability in society;

- to carry out prevention of corruption crimes in the economic sphere.

The implementation of this system will make it possible to make full use of preventive opportunities, timely and adequately respond to administrative and other offenses, to fully 
use administrative and legal means of influencing criminogenic factors and measures provided for by criminal procedure and other legislation.

\section{References}

1. Ivanov, M.G. (2018). To questions of economic substantiation of systematization of economic crimes. Retrieved from: https : // cyberleninka . ru/article/n/the $\mathrm{k}$ - voprosam - ekonomicheskogo - obosnovaniya - sistematizatsii - prestuplenii - e konomicheskoi - napravlennosti.

2. Kuznetsov, A. P. (2017). Economic crime and economic crime: the relationship of concepts. Legal Science and Practice, 3(39).

3. Mazhitova, S.R. (2011). On the problem of defining the concept of "Economic crime". Bulletin of Chelsu, 35.

4. Lopashenko, N. A. (2015). Crimes in the field of economic activity: theoretical and applied analysis. Moscow : Jurlitinform.

5. Luneev, V. V. (2019). Criminology. Moscow : Yurayt Publishing House.

6. Tsiklauri, V., Devyatilova, A., Artemov, R.,Markina, S.(2017). Shadow globalization as a threat to world economic growth. In: Soliman, K.S. (Eds.), The 29th International Business Information Management Association Conference (pp. 2478-2489). Viena: Proceedings Paper.

7. Klimenko, P., Markina, S., Mashkina, N. (2017). The influence of processes of financial globalization and transformation on the word financial and credit system. SGEM International Multidisciplinary Scientific Conference on Social Sciences and Arts.

8. Tsiklauri, V., Sevryukova, L., Devyatilova, A., Belousova, S. (2019). Bankruptcy Of Enterprises As An Indicator Of Disturbance Of Sustainable Economic Development. In: Soliman, KS (Eds.), Proceedings of the 33rd International Business Information Management Conference, IBIMA 2019: Education Excellence and Innovation Management through Vision 2020 (pp. 2395-2403). Garnada: Proceedings Paper.

9. Rykunova, V., Goncharenko, L., Belousova, S. (2019). Enhancement Of The Function Of Economic Incentive Mechanism For Natural Resources Management Rational. In: 17th International Scientific Multidisciplinary Geoconference SGEM 2017 (pp. 285-292). Sofia: Proceedings Paper.

10. Kirilchuk, I., Rykunova, V., Panskov, V. (2018). Features Of Calculation And Analysis Of Ekology- Ekonomic Index Of The Region On The Example Of Kursk Region. In: International Multidisciplinary Scientific GeoConferences SGEM 2018 (pp. 375-382). Sofia: Proceedings Paper.

11. Tkacheva, T.Y., Sevryukova, L.V, Afanasyeva, L.V. (2016). Organizational and Functional Features of Fiscal Mechanisms: Theoretical Aspects and Current Trends. The Social Sciences, 11(15), 3692-3696.

12. Tkacheva, T.Y., Afanasjeva, L.V. Sevrukova, L., Goncharenko, I., Panskov, V.G. (2019). Formation of modern fiscal mechanisms: integrated approach. In: Soliman, KS (Eds.), Proceedings of the 33rd International Business Information Management Conference, IBIMA 2019: Education Excellence and Innovation Management through Vision 2020 (pp. 9578-9582). Garnada: Proceedings Paper. 
13. Sevryukova, L., Belousova, S. (2016). Trends in taxation of personal income: Russian and foreign experience. Ekonom i chniy chasopis, 22(3-4). 41-43.

14. Kirilchuk, I., Rykunova, V., Panskov, V. (2018). Indicators Of Sustainable Development As Indicators Of Ecological-Economic Safety. In: 18th International Multidisciplinary Scientific GeoConferences SGEM (pp. 491-498). Sofia: Proceedings Paper.

15. Russia included in the top five for economic crime. Retrieved from: https: //www.rbc.ru/economics/ 16/11/2019 / 5af9c1aa9a7947ca948205bd

16. Galbreath, J., Lucianetti, L., Tisch, D., Thomas, B. (2020). Firm strategy and CSR: The moderating role of performance management systems. Journal of Management \& Organization, 1-19.

17. Muurlink, O., Macht, S. (2020). Managing (out) corruption in NGOs: A case study from the Bangladesh delta. Journal of Management \& Organization, 1-16. 